\title{
EFFECT OF AIR CONDITION ON AP-1000 CONTAINMENT COOLING PERFORMANCE IN STATION BLACK OUT ACCIDENT
}

\author{
Hendro Tjahjono \\ Center for Nuclear Reactor Technology and Safety \\ National Nuclear Energy Agency of Indonesia (BATAN) \\ Puspiptek Area, Building No.80 Serpong \\ Tangerang Selatan 15310, Indonesia \\ Email: hendro@batan.go.id, telp: 021-7560912, fax: 021-7560913 \\ Diterima editor: 1 September 2015 \\ Direvisi editor: 18 September 2015 \\ Disetujui untuk publikasi: 30 September 2015
}

\begin{abstract}
EFFECT OF AIR CONDITION ON AP-1000 CONTAINMENT COOLING PERFORMANCE IN STATION BLACK OUT ACCIDENT. AP1000 reactor is a nuclear power plant generation III+ $1000 \mathrm{MWe}$ which apply passive cooling concept to anticipate accidents triggered by the extinction of the entire supply of electrical power or Station Black Out (SBO). In the AP1000 reactor, decay heat disposal mechanism conducted passively through the PRHR-IRWST and subsequently forwarded to the reactor containment. Containment externally cooled through natural convection in the air gap and through evaporation cooling water poured on the outer surface of the containment wall. The mechanism of evaporation of water into the air outside is strongly influenced by the conditions of humidity and air temperature. The purpose of this study was to determine the extent of the influence of the air condition on cooling capabilities of the AP1000 containment. The method used is to perform simulations using Matlab-based analytical calculation model capable of estimating the power of heat transfered. The simulation results showed a decrease in power up to $5 \%$ for relative humidity rose from $10 \%$ to $95 \%$, while the variation of air temperature of $10{ }^{\circ} \mathrm{C}$ to $40^{\circ} \mathrm{C}$, the power will decrease up to $15 \%$. It can be concluded that the effect of air temperature increase is much more significant in lowering the containment cooling ability compared with the increase of humidity.
\end{abstract}

Keywords: containment cooling, AP1000, air condition, SBO

\section{ABSTRAK}

PENGARUH KONDISI UDARA TERHADAP KINERJA PENDINGINAN SUNGKUP AP-1000 DALAM KECELAKAAN STATION BLACK OUT. Reaktor AP-1000 merupakan PLTN generasi III+ berdaya 1000 MWe yang menerapkan konsep pendinginan pasif untuk mengantisipasi terjadinya kecelakaan yang dipicu oleh padamnya seluruh suplai daya listrik atau dikenal dengan Station Black Out (SBO). Pada reaktor AP1000, mekanisme pembuangan kalor peluruhan dilakukan secara pasif melalui PRHR yang diteruskan ke IRWST dan selanjutnya pada sungkup reaktor. Sungkup didinginkan secara eksternal melalui konveksi alamiah pada celah udara dan melalui penguapan air pendingin yang diguyurkan di permukaan luar dinding sungkup. Mekanisme penguapan air ke udara luar sangat dipengaruhi oleh kondisi kelembaban dan temperatur udara. Tujuan dari penelitian ini adalah untuk mengetahui sejauh mana pengaruh kondisi udara tersebut terhadap kemampuan pendinginan dari sungkup AP1000. Metode yang digunakan adalah dengan melakukan simulasi menggunakan model perhitungan analitis berbasis Matlab yang mampu mengestimasi daya kalor yang dievakuasi. Hasil simulasi menunjukkan adanya penurunan daya hingga 5\% untuk kelembaban relatif naik dari $10 \%$ hingga $95 \%$, sedangkan untuk variasi temperatur udara dari $10^{\circ} \mathrm{C}$ hingga $40^{\circ} \mathrm{C}$, daya akan menurun hingga $15 \%$. Dapat disimpulkan bahwa pengaruh kenaikan temperatur udara jauh lebih signifikan dalam menurunkan kemampuan pendinginan sungkup dibandingkan dengan naiknya kelembaban.

Kata kunci: pendinginan sungkup, AP1000, kondisi udara, SBO 


\section{INTRODUCTION}

In a PWR-typed nuclear power plant, the containment becomes the last barrier to prevent the release of radioactive material to the environment. In addition, the containment also serves to protect the entire reactor system to the dangers that come from the outside like an airplane crashed, tornadoes, floods, tsunami, bombs, etc. Therefore, the integrity of the containment must always be maintained to identify all sources of interference and its mitigation. The cause of the damage is greatest when the containment pressure rises to exceed the design pressure as a result of the abundance of vapor or gas production due to an accident. In addition, the increase in pressure can also be caused by an explosion of accumulated hydrogen gas. The gas is produced as a reaction of the fuel cladding containing zirconium with water vapor at high temperatures as occurred in the Fukushima Daiichi Nuclear Power Plant. Although not a PWR type reactors but BWR, but still there are some things that could be taken as a lesson because it can also occur in the PWR type. One of the important lessons of the Fukushima incident is the impact of the loss of the total ac electrical power or commonly known as a "station blackout" which turned out to be very dangerous if not well anticipated to occur in the PWR type. Fukushima accident has also been evidence of the importance of the implementation of passive safety in the reactor system, which does not depend on the external electrical power supply. One design of generation III+ reactor that implements the concept of passive safety is the AP1000 reactor.

Andi Sofrany et al [1] have verified the occurrence of feed water loss due to the electrical power loss of a secondary pump on the AP1000 using RELAP5 Code. The result shows that the containment pressure rise could exceed the design pressure if not mitigated with a splash of water on the surface of the outer wall of the containment. Therefore the passive cooling through natural convection with air flow is not sufficient and should be aided by cooling through evaporation of water that poured from a reservoir at the top of the containment. The greater rate of water evaporation at the containment surface will increase the cooling rate of the containment.. The higher humidity and air temperature will decrease the containment evaporation rate. However, the variations of humidity and air temperature is very wide in this world depended on time and place. In a country that experiences four seasons, the air temperature can vary from $-20{ }^{\circ} \mathrm{C}$ to $+40{ }^{\circ} \mathrm{C}$ throughout the year, relative humidity can also vary depending on the place and time ranging from $20 \%$ to $95 \%$. Several studies have been conducted by Wang Yan give some numerical analysis of the containment external cooling passively on advanced PWR[2,3]. Xi Huang and Xu Cheng have proposed a modification of water film model for PWR's passive containment cooling [4].Yu Yu et al. provided a one-dimensional model for containment in AP1000 nuclear power plant based on thermal stratification [5], Janusz Dziak et al. have provided the results of numerical simulation of the cooling process through a thin layer of water [6], Ye Cheng et al. have studied numerically passive cooling process in a relatively long period of time numerically[7]. Hendro Tjahjono [8] has developed a MATLAB-based analysis program for the optimal splash flow rate to produce the highest heat transfer capability, and Kozanoglu et al. [9] have also contributed to publish the results of research on cooling through evaporation of a thin layer. Containment volume effect on the pressure and temperature during LOCA in AP1000 reactor containment has been studied by Farzad Choobdar Rahim [10]. According to SBO and its effect on containment pressure and temperature, several studies have also been performed [11-14]. From all the results of these studies the effect of air temperature and humidity conditions on the ability to transfer the heat shield has not been specifically investigated.

This research aims to determine the extent of the influence of variations in humidity and ambient air temperature on the ability of the containment in evacuating the decay heat in the accident a "station blackout" through the evaporation of a thin layer of water on the surface of the containment.

The method used is through numerical simulation using Matlab-based calculation program that has been developed in a previous study [8], with the first modified as necessary to investigate the influence of air humidity and temperature. Advanced PWR reactor data investigated is taken from the data of the AP1000 PWR reactors that have been studied in previous research. As a research variable, relative humidity is varied from 10 to $100 \%$ and the air temperature varied from $1{ }^{\circ} \mathrm{C}$ to $40^{\circ} \mathrm{C}$. The 
parameters calculated in this case is the maximum heating power, which can be transfered by the splash shield on the optimal flow conditions. With this study are expected to know how far the AP1000 containment capability will be reduced if operated in Indonesia with temperature and humidity are on average higher than in countries where the reactor is designed.

\section{THEORY}

The concept of containment external cooling was already applied in the design of advanced generation of nuclear power plants such as the AP1000 or AP600 which is a version of the first, long before the Fukushima Daiichi accident. In addition to applying the concept of external cooling, passive cooling concept is also applied through the application of chimney effect cooling with air, and the application of the force of gravity to cooling with water splash through the water reservoir above the placement of the containment. The volume of water in the reservoir is around $3000 \mathrm{~m} 3$ designed to be able to cool for 72 hours. Schematic figure of the passive containment cooling of AP1000 reactor is given in Figure 1 [11]. When there is an accident that led to the rise in temperature inside the lid, then this will trigger a natural convection on the surface because the air is heated lid will be lighter and tend to be lifted. Air holes in the top of the containment will provide the chimney effect that increase the lifting force of the air, thus increasing the flow. Cold air from the outside will be sucked in through the holes provided at the top. If the cooling air is insufficient, the containment pressure and temperature continues to rise until the pressure reached 1.7 bar absolute, then the cooling water valve will open automatically and the water splashed onto the surface of the containment. Cooling is expected to take place through the mechanism of evaporation so that the flow of poured water should be optimized. That should be sufficient but not excessive to keep the evaporation mechanism is most effective.

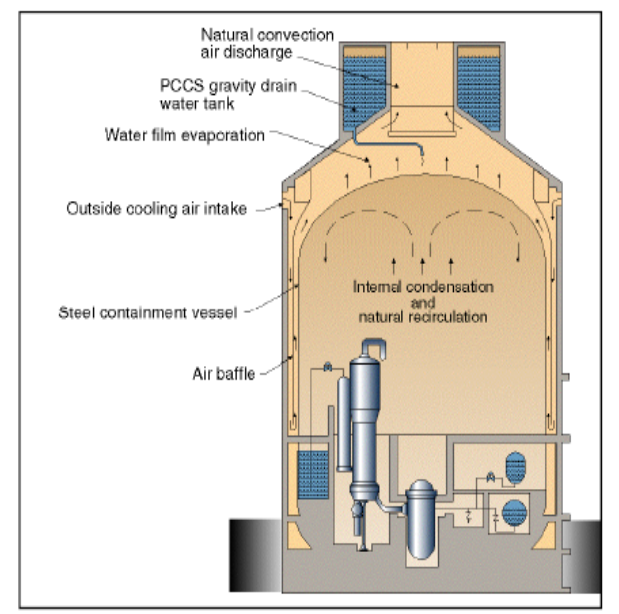

Figure 1. AP1000 Containment Passive Cooling System [12]

In this case the coolant flow is modeled as a laminar flow which forms a thin layer on the surface of the lid as shown in Figure 2. The heat transfer mechanism is from the inside to the outside takes place by convection with condensation on the internal surface, then the containment wall conduction, conduction in a thin water layer and evaporation at the surface of the cooling water layer. When the temperature of the water layer has reached its boiling temperature $\left(100{ }^{\circ} \mathrm{C}\right)$, then there is boiling in the water layer which accelerate the rate of evaporation. In this case it is assumed that the flow does not break that will reduce the surface area of contact with the surface of the containment. The non wetted containment surface is assumed to only be caused by the expiration of water due to evaporation, not for other reasons such as broken stream. Cooling mechanism in the dry areas take place through convection and radiation between the containment surface and air. During the boiling process takes place, the containment surface temperatures will be slightly above the boiling temperature, but when the cooling water evaporates, the surface of the lid will be dry and cooling will be much reduced so that the containment surface temperature will rise. Simulation results using this 
model have been compared with the design data by finding the optimal discharge of cooling water, which is providing the maximum heat transfer, on the maximum containment temperature conditions. It is obtained that the optimal flow is not much different from the average flow of water splash in the AP1000 to spend the amount of water stored in the reservoir of $3000 \mathrm{~m}^{3}$ for 72 hours. Thus the flow and heat transfer models used can be applied to investigate the influence of outside air conditions for the containment cooling process.

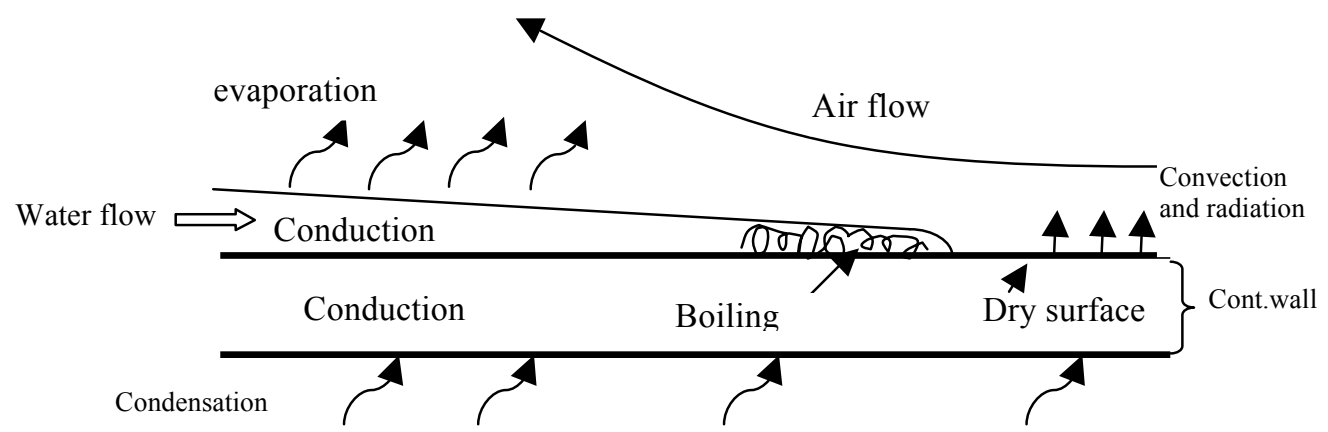

Figure 2. Containment cooling mechanism model (reproduced from [8])

On the containment surface, heat transfer takes place through the mechanism of condensation of vapor mixed with air as existing before the accident occurred, the containment containing air with a pressure of about 1 atmosphere, and the air mass inside the containment is assumed to be constant. Thus, to calculate the heat transfer coefficient used empirical equation involving the influence of non-condensable gases. On the outer surface of the containment, the mechanism of heat transfer by convection flow is assumed to be ignored compared to the conduction due to the slow and thin stream.

On the surface of the cooling water, the heat transfer takes place through evaporation which is facilitated by the presence of convection air flow due to the chimney effect. The evaporation is an event of loss of water molecules on the surface when there is a difference concentration between the water vapor near the surface area and the further positions area. Evaporation is the change of phase to the form of water vapor, evaporation occurs only at the surface of the water while boiling occurs in the entire volume. Because each event to change the form of water vapor is always need heat of large enough, then the event will also provide the evaporation heat transfer coefficient relatively large when compared with convection without phase change. Kroger and Branfield [15] proposed a correlation for evaporation heat transfer coefficient as given in equation 1 .

$$
h_{u}=\frac{0,2106+0,0026 \cdot v_{a}\left(\frac{\rho_{a v}{ }^{2}}{\mu g\left(\rho_{a v i}-\rho_{a v o m}\right)}\right)^{1 / 3}}{\left(\frac{\mu}{g c_{P} \rho_{a v} k^{2}\left(\rho_{a v i}-\rho_{a v o m}\right)}\right)^{1 / 3}}
$$

where $\mathrm{h}_{\mathrm{u}}$ : evaporation heat transfer coefficient $\left(\mathrm{W} / \mathrm{m}^{2} \mathrm{~K}\right)$

$\mathrm{v}_{\mathrm{a}}:$ water flow velocity $(\mathrm{m} / \mathrm{s})$

$\mu$ : dynamic viscosity of water $(\mathrm{kg} / \mathrm{m} . \mathrm{s})$

$\rho_{\text {avi: }}$ initial density of moist air in a free environment $\left(\mathrm{kg} / \mathrm{m}^{3}\right)$

$\rho_{\text {avom: }}$ : the density of moist air at the surface of water $\left(\mathrm{kg} / \mathrm{m}^{3}\right)$

$\rho_{\mathrm{av}}$ : the density of moist air on average $\left(\mathrm{kg} / \mathrm{m}^{3}\right)$ 
The density of moist air in early-free environment is determined from the level of humidity, and can be calculated using equation 2 .

$$
\rho_{a v i}=\left(1+W_{i}\right)\left[1-\frac{W_{i}}{W_{i}+0,622}\right]\left(\frac{p_{a}}{287,08 T_{a}}\right)
$$

with Wi: ratio between the mass of water vapor to the mass of dry air, with

$$
W_{i}=0,622 \frac{p_{v i}}{p_{a}-p_{v i}}
$$

$\mathrm{p}_{\mathrm{a}}$ : ambient air pressure $(\mathrm{Pa})$

$\mathrm{T}_{\mathrm{a}}$ : ambient air temperature $(\mathrm{K})$

$\mathrm{p}_{\mathrm{vi}}$ : relative pressure of vapor $(\mathrm{Pa})$, calculated with

$$
p_{v i}=\Phi \times 2,368745 \times 10^{11} \exp \left(-\frac{5406,1915}{T_{a}}\right)
$$

With $\Phi$ is relative humidity of air.

Parameter $T_{a}$ and $\Phi$ are main variables in this research.

Similarly, for the density of moist air at the water surface can be calculated using equation

$$
\text { 5. } \rho_{\text {avom }}=\left(1+W_{o}\right)\left[1-\frac{W_{o}}{W_{o}+0,622}\right]\left(\frac{p_{a}}{287,08 T_{o}}\right)
$$

with Wo: ratio between the mass of water vapor to the mass of dry air, with

$$
W_{o}=0,622 \frac{p_{v o}}{p_{a}-p_{v o}}
$$

$\mathrm{T}_{\mathrm{o}}$ : air temperature in water surface $(\mathrm{K})$, equal to the temperature of the water surface

$\mathrm{p}_{\mathrm{vo}}$ :relative pressure of water vapor at the surface $(\mathrm{Pa})$, which can be calculated using equation 4 by taking the relative humidity at the surface of the water $\Phi=1$

When the temperature of the cooling water reaches boiling temperature, then the boiling process occurs which will accelerate the rate of evaporation. In this boiling, the conduction mechanism in the cooling layer is ignored because of in the homogen temperature so that the mechanism of heat transfer takes place entirely through boiling, followed by air convection mechanism. When most of the surface becomes dry, the heat transfer mechanism in the section takes place in the air convection and radiation.

Total heat transfer mechanism of vapor and air mixture inside the containment into the air outside is modeled as a set of thermal resistance in series which impede the flow of the heat flux from the inside to the outside air. This series connection of resistance gives the total resistance is the sum of all the resistance.

\section{METHODOLOGY}

In the investigation of the influence of the air condition used Matlab-based calculation program that has been developed in previous research by performing the necessary modifications associated with suppression of an investigation of the effects of air condition [8]. Modifications done by adding an iterative algorithm to repeat the whole process of calculating the maximum heat transfered for each stage of the air condition parameter changes. This algorithm also gives the possibility to recalculate every physical properties such as air density, viscosity, conductivity, for 
each stage of the change in temperature and humidity. Parameters of air condition simulated is air temperature and relative humidity. While external cooling parameters measured were the maximum amount of heat to be transfered by the containment and optimal flow at the maximum heating power. Compared also in this case, two much different air conditions.

To get the profile of maximum heat power transfered changes as a function of temperature and humidity, air temperature simulated variable ranging from $1{ }^{\circ} \mathrm{C}$ to $40{ }^{\circ} \mathrm{C}$, while the relative humidity simulated variable ranging from $10 \%$ to $95 \%$. The selected internal temperature is $145^{\circ} \mathrm{C}$, i.e the temperature at a pressure of approximately 5 bar, which is the maximum allowable pressure. It is taken to evaluate whether the maximum temperature of the containment cooling system is still able to e the decay heat power at the time.

\section{RESULTS AND DISCUSSION}

In Figure 3 is shown the curve OF maximum heat can be transfered by the containment cooling system at a temperature of $145^{\circ} \mathrm{C}$ as a function of cooling flow for two vastly different air conditions, i.e at $95 \%$ humidity with $40{ }^{\circ} \mathrm{C}$ of temperature and $20 \%$ humidity with $5{ }^{\circ} \mathrm{C}$ of temperature. On the condition of the very hot and humid air, like in Indonesia, the heat power can be transfered is $20.5 \mathrm{MW}$ achieved in the flow of 9.5 liters / sec, whereas if it is built in a subtropical countries with low humidity and temperature, heat power could be transfered could reach 24.6 MW reached at flow of 11 liters/sec. From the decay heat curve shown in Figure 4, approximately 24 hours after shutdown, there are approximately $0.5 \%$ of initial power or around 15 MW that must be transfered and will be smaller after that time. Thus, the hot and humid conditions such as those exemplified above, the performance of the containment is still able to transfer the decay heat.

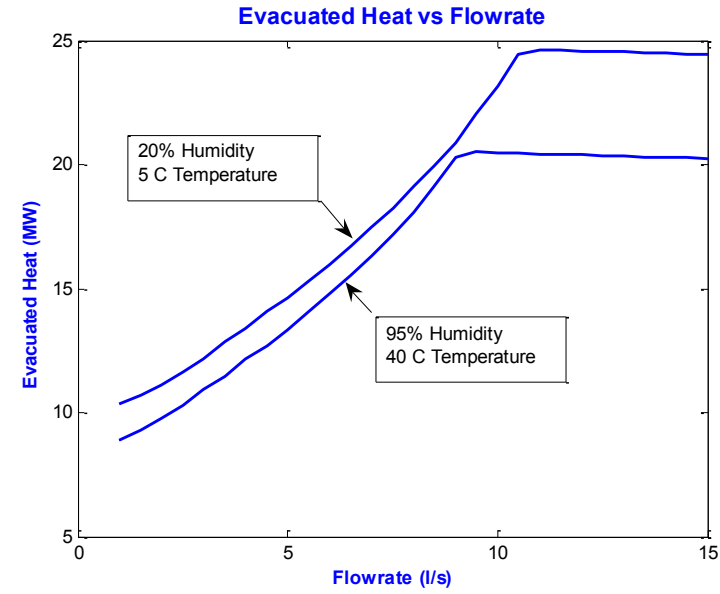

Fig 3. Effect of ambient conditions to AP1000 transfered/evacuated heat

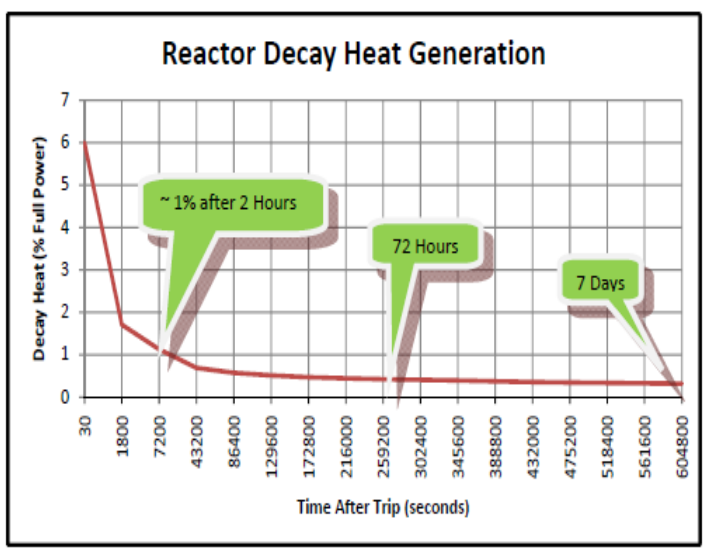

Fig 4. AP1000 decay heat curve [14]

In Figure 5(a) shown the simulated performance profile of containment in evacuating heat as a function of humidity for 4 different temperatures, while the profile is shown in Figure 5(b) the heat power changes with temperature. It is seen that the effect of humidity on power is not significant because it fell no more than $5 \%$ in the range of simulated moisture. Relatively significant is the effect of air temperature, which provides power reduction of $15 \%$ for the air temperature rise of $1{ }^{\circ} \mathrm{C}$ to $40^{\circ} \mathrm{C}$. 


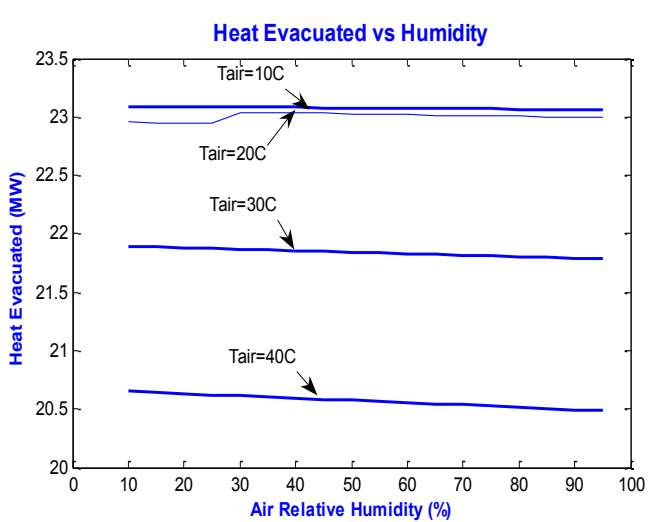

(a) Heat Transfered/evacuated vs Humidity

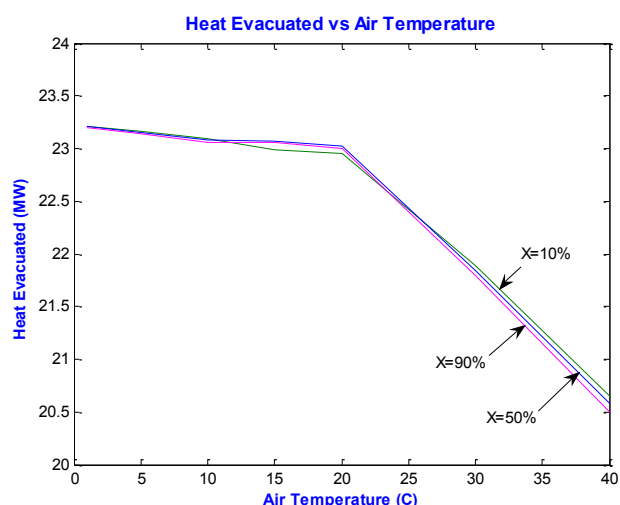

(b) Heat Transfered/evacuated vs Air Temperature

Figure 5. Effect of humidity and temperature on the maximum heat transfered at a temperature containment of $145^{\circ} \mathrm{C}$

As particular interest is the presence of a fault curve in the area around $20{ }^{\circ} \mathrm{C}$. This can be explained by looking at the curve of the heat flux along the walls of the containment shown in Figure 6. It is seen that for the air temperature less than $20{ }^{\circ} \mathrm{C}$, the cooling water is no longer sufficient due to evaporation so that most of the surface of the containment to be dry which will decrease the flux. As a result, for temperature less than $20{ }^{\circ} \mathrm{C}$, the change in total power as the integral of the flux across the surface of the containment is not as sharp as when the ambient temperature is above $20^{\circ} \mathrm{C}$.

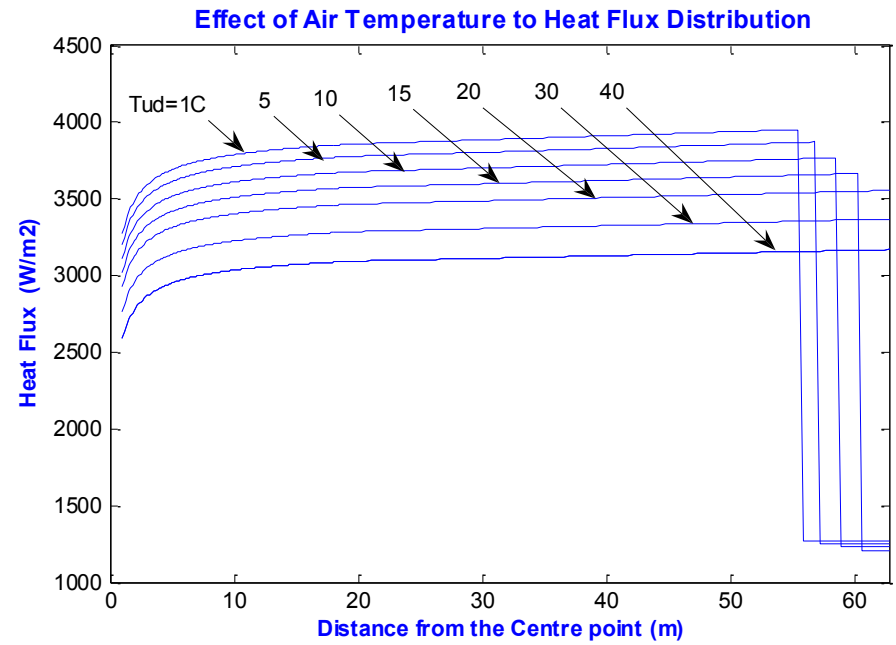

Figure 6. Heat flux transfered along the containment surface

Those results have been done in the containment temperature condition of $145^{\circ} \mathrm{C}$ which is the maximum allowable temperature of the containment. For the temperature of less than this limit, the heat flux should be reduced. However, the effect of ambient temperature to the transfered heat should remain bigger compared to the effect of ambient humidity.

\section{CONCLUSION}

From this study it can be concluded that the AP1000 containment performance is affected by the air condition in which the plant is built. The biggest influence on the parameters given by the temperature of the air condition while air humidity does not have a significant influence on the 
performance of the containment heat transfer. The higher the temperature and humidity, the lower the ability to transfer the heat shield. In hot humid air containment capabilities in evacuating the heat can go down up to $20 \%$ compared with the dry winter air. However, the containment capability is sufficient to transfer the decay heat.

\section{ACKNOWLEGMENT}

Thanks go to fellow researchers in the analysis and simulation of reactor safety group on Reactor Safety Technology for the willingness to discuss and give false advice related to this research.

\section{REFERENCES}

1. Andi Sofrany Ekariansyah, Surip Widodo, Susyadi, D.T. Sony Tjahyani, Hendro Tjahjono, "Verification of Loss of Feed Water Flow Accident In Advanced PWR Nuclear Power Plant", Journal of Nuclear Reactor Technology, Vol. 14 No.2 June 2012, pp. 76-90.

2. Wang Yan, "Analysis Model for the Passive Containment Cooling System", Journal of Convergence Information Technology (JCIT), Volume 7, Number 13, July 2012.

3. Wang Yan, "Preliminary Study for the Passive Containment Cooling System Analysis of the Advanced PWR", Asian Nuclear Prospects 2012, Energy Procedia 39, pages 240 - 247, 2013.

4. Xi Huang, Xu Cheng, Modification and application of water film model in COCOSYS forPWR's passive containment cooling, Nuclear Engineering and Design 280 (2014) 251261.

5. $\mathrm{Yu} \mathrm{Yu,} \mathrm{Fenglei} \mathrm{Niu,} \mathrm{Shengfei} \mathrm{Wang,} \mathrm{Yingqiu} \mathrm{Hu,} \mathrm{"One-dimensional} \mathrm{model} \mathrm{for} \mathrm{containment}$ in AP1000 nuclear power plant based on thermal stratification", Applied Thermal Engineering 70 (2014) 25-32.

6. Janusz Dziak, Magdalena Kubala, "Heat and mass transfer during thin-film evaporation of two-component liquid solutions", 20th European Symposium on Computer Aided Process

7. YE Cheng, ZHENG Mingguang WANG Yong, QIU Zhongming, "Study on the long-term passive cooling extension of AP1000 reactor", Nuclear Science and Techniques 24 (2013) 040601.

8. HendroTjahjono, "Optimization Of External Cooling On PWR-1000 Containment Model Using Analytical Estimation Method", Journal of Reactor Technology “Tri Dasa Mega”,June 2014.

9. Kozanoglu, B., Rubio, F., "The Characteristic Length on Natural Convection From A Horizontal Heated Plate Facing Downwards, Journal of Thermal Science, Year 2014, Vol. 18, No. 2.

10. Farzad Choobdar Rahim, "Analysis of Containment Volume Effect on the Pressure and Temperature during LOCA in the AP1000 Reactor Containment", IJNESE Volume 2, Issue 3 September 2012,pp. 92-96.

11. YE Cheng, ZHENG Mingguang WANG Yong, QIU Zhongmin," Study on the long-term passive cooling extension of AP1000 reactor", Nuclear Science and Techniques 24 (2013)

12. Westinghouse Non-Proprietary Class 3, "Westinghouse AP1000 Nuclear Power Plant Coping with Station Blackout", April 2011.

13. Andrija Volkanovski, Andrej Prosek, "Extension of station blackout coping capability and implications on nuclear safety",Nuclear Engineering and Design 255 (2013) 16- 27.

14. Liang Hu, Yapei Zhang, Longze Li, G.H. Su, Wenxi Tian, Suizheng Qiu, "Investigation of severe accident scenario of PWR response to LOCA along with SBO", Progress in Nuclear Energy 83 (2015) 159-166.

15. D.G.Kroger dan G.R.Branfield. Evaporation from a Water Surface. R\&D Journal of South African Institution of Mechanical Engineering No. 23 (3), 2007. 